\title{
Breast cancer growth and metastasis: interplay between cancer stem cells, embryonic signaling pathways and epithelial-to-mesenchymal transition
}

\author{
Naoko Takebe*1, Ronald Q Warren² and S Percy Ivy ${ }^{* 1}$
}

\begin{abstract}
Induction of epithelial-to-mesenchymal transition (EMT) in cancer stem cells (CSCS) can occur as the result of embryonic pathway signaling. Activation of Hedgehog (Hh), Wnt, Notch, or transforming growth factor- $\beta$ leads to the upregulation of a group of transcriptional factors that drive EMT. This process leads to the transformation of adhesive, non-mobile, epithelial-like tumor cells into cells with a mobile, invasive phenotype. CSCs and the EMT process are currently being investigated for the role they play in driving metastatic tumor formation in breast cancer. Both are very closely associated with embryonic signaling pathways that stimulate self-renewal properties of CSCS and EMT-inducing transcription factors. Understanding these mechanisms and embryonic signaling pathways may lead to new opportunities for developing therapeutic agents to help prevent metastasis in breast cancer. In this review, we examine embryonic signaling pathways, CSCs, and factors affecting EMT.
\end{abstract}

\section{Introduction}

Breast cancer stem cells (CSCs) are increasingly thought to play a major role in breast cancer growth and the formation of metastases. CSCs have hierarchical potential to undergo self-renewal along with yielding daughter cells that result in the formation of bulk tumor cells, while maintaining a self-replicating potential [1]. CSCs

\footnotetext{
*Correspondence: ivyp@ctep.nci.nih.gov; takeben@mail.nih.gov 'National Cancer Institute, Division of Cancer Treatment and Diagnosis, Cancer Therapy Evaluation Program, Investigational Drug Branch, EPN 7131, 6130 Executive Boulevard, Rockville, Maryland 20852, USA

Full list of author information is available at the end of the article
}

appear to make up a small minority of most tumors, while in others (for example, melanoma) they may comprise up to $25 \%$ of the total mass [2].

Epithelial-to-mesenchymal transition (EMT), a process first noted during embryogenesis, guides the transformation of non-mobile epithelial-like cells into mobile, mesenchymal-like cells that have the potential to travel to distant anatomical sites within the developing embryo (Figure 1). This naturally occurring process has also been observed during tumor formation, and may lead to the development of metastatic growth. The process can be reversed through mesenchymal-to-epithelial transition (MET), where migratory cells become anchored at distant sites and lose their migratory potential.

Embryonic signaling pathways, such as the Notch, Hedgehog (Hh), Wnt, and transforming growth factor (TGF)- $\beta$ pathways, are essential for stem cell signaling during embryogenesis [3]. These pathways play critical roles in normal tissue development and maintenance, and are also involved in the tight regulation of EMT. Deregulation of embryonic signaling pathways has been widely reported in human cancers, including breast, pancreatic, and lung [4-6]. This observation has led to the evaluation of these pathways as potential targets for a new generation of anti-cancer drugs.

This review examines current findings and perspectives on the interplay between CSCs, embryonic signaling pathways, and EMT/MET in breast tumor growth and metastasis.

\section{Breast cancer stem cells}

The cell-of-origin for breast CSCs has yet to be determined, but may be the result of malignant transformation of normal stem/progenitor cells [7]. The long life span of stem/progenitor cells makes them more susceptible to the accumulation of DNA mutations. The capacity to replicate and produce multiple progeny also makes stem and progenitor cells likely candidates for tumor cells-oforigin [8]. 


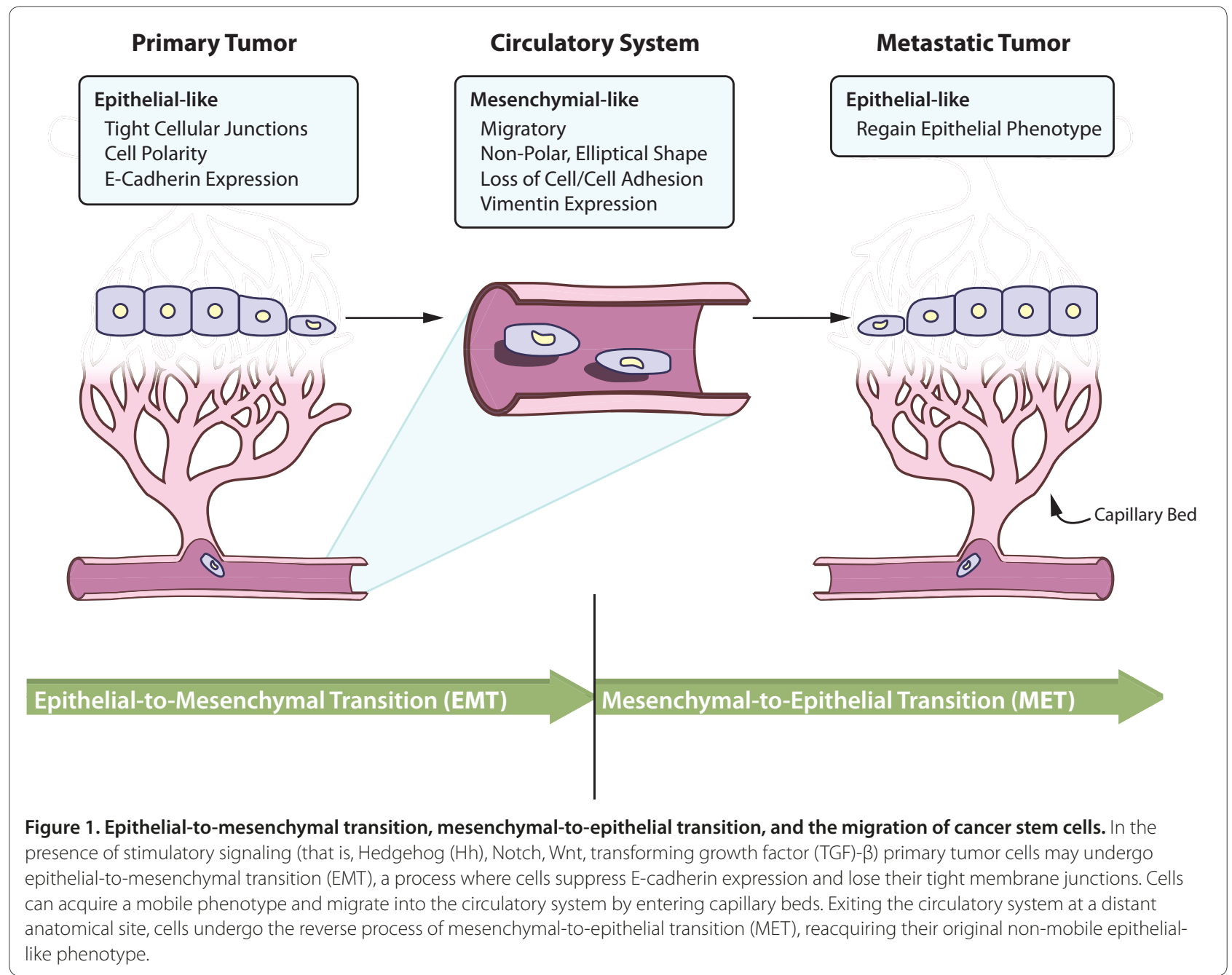

BRCA1 is known to play a role in the repair of doublestranded DNA breaks in breast tissue, thereby maintaining chromosomal stability and structure [9]. BRCA1 expression is required for the differentiation of estrogen receptor (ER') stem/progenitor cells into $\mathrm{ER}^{+}$luminal cells. Loss of the double-stranded DNA break repair function, seen in BRCA1 deficient or mutant cells, may contribute to the accumulation of genetically unstable breast stem cells, providing a source of cells suitable for carcinogenesis and CSC development [10].

Breast CSCs capable of forming mammospheres were isolated from pleural effusions from breast cancer patients, and were tumorigenic when transplanted into SCID mice [11]. Breast CSCs expressed CD44, but had low or undetectable levels of CD24 and were lineage negative $\left(\mathrm{CD} 44^{+} \mathrm{CD} 24^{-/ \text {low }} / \mathrm{lin}^{-}\right)$by flow cytometry [12]. NOD/SCID mice injected with as few as $200 \mathrm{ESA}^{+} \mathrm{CD}_{4} 4^{+}$ CD24-/low cells formed tumors that could be serially passaged in vivo. More recently, additional markers, including aldehyde dehydrogenase (ALDH)1, CD133 (prominin-1) [13], CD49f hi and ITGA6 [14], have been proposed as breast CSC biomarkers. ALDH1, a detoxifying enzyme that oxidizes intracellular aldehydes, is found in both normal mammary stem cells and breast cancer stem cell populations [15]. As few as $500 \mathrm{ALDH} 1^{+}$ breast tumor cells were capable of forming tumors when transplanted into NOD/SCID mice. An examination of ALDH expression in human breast cancer found that $\mathrm{ALDH}_{1}{ }^{+}$tumors were associated with HER2 expression, and the absence of ER and progesterone receptor expression (HER2 $\left.{ }^{+}, \mathrm{ER}^{-}, \mathrm{PR}^{-}\right)$. ALDH-1 expression in basal-type breast cell lines, but not most luminal cell lines, has been associated with a poor prognosis and decreased overall survival [16].

Significantly, these biomarkers are not expressed universally across all types of breast cancer CSCs, but rather are expressed differentially according to subtype $[13,16]$. In addition to histologic phenotype, biomarker expression may also be dependent upon the tumor microenvironment [17]. For example, the microenvironment 


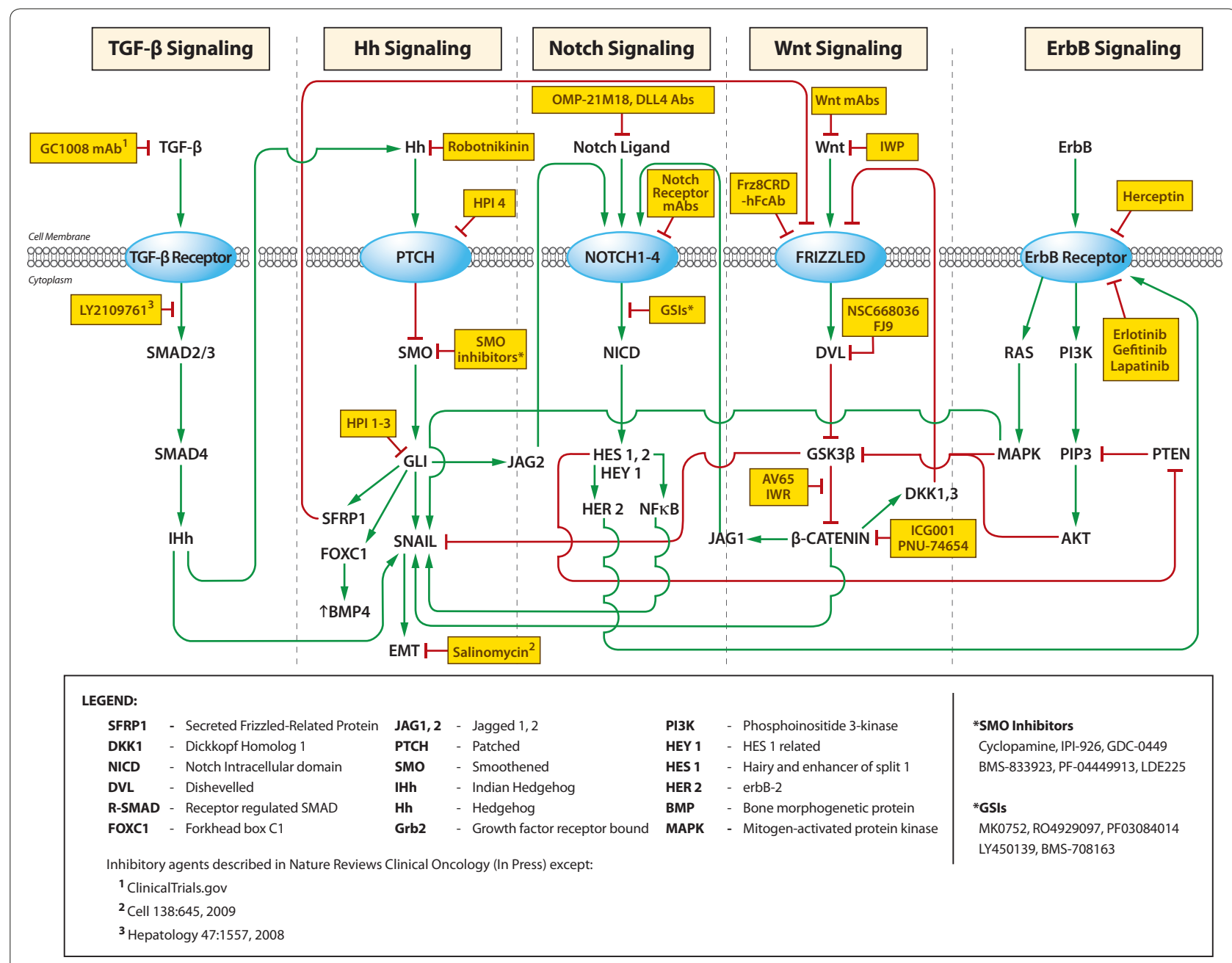

Figure 2. Cross-talk among embryonic signaling pathways and experimental inhibitors. Potential cross-talk among embryonic signaling pathways (transforming growth factor (TGF)- $\beta$, Hedgehog (Hh), Notch, Wnt, and ErbB) is shown. The expansive potential for signaling cross-talk suggests that signaling pathways do not function in isolation, but instead are parts of a complex signaling network. Cross-talk can lead to both enhancing and inhibitory interactions between pathways. The actions of experimental pathway inhibitors are shown in yellow. Positive interactions are shown in green, while negative interactions are shown in red.

may provide regulatory signals that modulate the activity of transcription factors and subsequent gene expression. The CSC microenvironment may also provide essential factors that help regulate EMT and MET processes and expression of resulting cellular phenotypes.

\section{Treatment-resistant CD44 ${ }^{+} / \mathrm{CD}^{2} 4^{-/ \text {llow }}$ cells}

The enrichment of $\mathrm{CD} 44^{+} / \mathrm{CD} 24^{-/ \text {low }}$ cells in primary breast tumors following chemotherapy suggests an innate resistance to standard treatments [18]. The presence of ATP-binding cassette $(\mathrm{ABC})$ transporters, including ABCG2, first cloned by Doyle and colleagues, is highly expressed in a subpopulation (that is, side population) of CSCs $[19,20]$. ABC transporters act to confer resistance to chemotherapeutic agents by extruding these compounds out of the cell [21].
Similarly, enrichment of CD44+/CD24-/low cells has been demonstrated following treatment with radiation therapy [22]. These cells were capable of reproducing in an in vivo model following at least four generations of xenograft transplanted mice [23], suggesting that they play important roles in tumor relapse and metastasis. Potential mechanisms of chemotherapy and radiation resistance in breast cancer include the presence of lower concentrations of reactive oxygen species [24], cell dormancy, efficient DNA repair mechanisms [25], and overexpression of Wnt/ $\beta$-catenin and Notch signaling $[22,26]$. Treatment-resistant $\mathrm{CD} 44^{+} / \mathrm{CD} 24^{- \text {/low }}$ cells, being potential cells-of-origin for metastatic growth, are currently being evaluated as therapeutic targets.

The stem cell niche may also furnish CSCs with a means to evade chemotherapy through the presence of a 
protective microenvironment [27]. The niche is a complex microenvironment that is actively involved in stem cell growth. The niche acts to shelter stem cells from apoptotic signals, differentiation stimuli, and environmental insults [28]. Bidirectional signaling occurs between the supporting niche and stem cells, and the possibility exists that dysfunctional signaling by the supporting niche may drive CSC growth. Therefore, targeting the CSC niche with new therapeutic agents may disrupt these cellular communications and potentially interfere with CSC growth.

\section{Cross-talk among embryonic signaling pathways}

The Hh, Notch, Wnt, and TGF- $\beta$ signaling pathways, instead of acting as isolated units, may interact through cross-talk to provide tumor cells with an additional mechanism to evade chemotherapy (Figure 2) [29]. The links between embryonic Hh signaling and EMT are relatively well established, but must also be considered in a context-dependent fashion as extensive evidence of cross-talk between the embryonic signaling pathways also occurs. These interlinked network communications may serve as a natural mechanism to increase cellular diversity to extracellular stimuli during embryogenesis and postnatal life. The identification of cross-talk networks in tumor cells may also allow for more effective design and use of combination anti-tumor therapies.

The TGF- $\beta$ signaling pathway is known to interact with the Wnt, Hh, and Notch pathways, as well as the mitogen-activated protein kinase (MAPK) pathway [30]. These interactions are complex, context dependent, and reflective of the summary of all input signals. TGF- $\beta$ signaling helps regulate a wide spectrum of cellular processes, including proliferation, differentiation, apoptosis, cell migration, and metastasis [31]. Understanding the consequences of TGF- $\beta$ cross-talk with other signaling pathways during tumorigenesis is key to developing effective therapeutic strategies.

Links between HER2 overexpression and activation of the phosphoinositide 3-kinase (PI3K)/Akt pathway suggests cross-talk between these pathways in breast tissue [32]. Treatment of sensitive HER2 ${ }^{+}$cell lines in vitro with trastuzumab led to decreased expression of both phospho-HER2 and phospho-Akt. In resistant HER2 ${ }^{+}$cells, trastuzumab treatment had no measurable effect on either HER2 or Akt phosphorylation.

A Notch binding sequence has been reported within the HER2 promoter and suggests a mechanism for Notch/ HER2 cross-talk [33]. HER2 expression was shown to be dependent upon Notch signaling in stem-like breast cells [34]. Inhibition, or silencing of Notch signaling, resulted in reduced HER2 expression by these cells. Thus, combining Notch inhibitors with anti-HER2 agents may yield positive results in HER2 ${ }^{+}$breast cancer patients.
Also, cross-talk between Notch and the ER has been reported in breast cancer cell lines in vitro [35]. Estrogen was shown to inhibit Notch signaling through a mechanism partly mediated by inhibition of Notch cleavage by $\gamma$-secretase. Treatment of $\mathrm{ER}^{+}$cell lines with antiestrogens (for example, estradiol) strongly upregulated Notch signaling and led to cell proliferation. Results indicated that Notch signaling may represent a therapeutic target in ER $\alpha$ breast cancers. Conversely, combination therapies of Notch inhibitors and anti-estrogens may be effective in $\mathrm{ER}^{+}$breast cancers.

\section{Notch signaling}

The Notch receptors and their ligands moderate short range cellular communications during proliferation, differentiation, embryogenesis and apoptosis [36]. The Notch receptors consist of non-covalently bound extracellular, transmembrane and intracellular domains. Notch receptors interact with a diverse group of ligands from the Delta (-1, -3 and -4$)$ and Serrate/Jagged families ( -1 and $-2)$. Receptor cleavage, with eventual release of the Notch intracellular domain (NICD), occurs through a disintegrin and metalloprotease (ADAM) followed by $\gamma$ secretase cleavage. Once released from the membrane receptor, NICD translocates to the nucleus where it interacts with the CSL transcription factor to activate the Notch target genes such as HES, HEY and c-Myc [37]. Currently, $\gamma$-secretase and aspartyl protease serve as primary targets for Notch-specific investigational drug design.

Although cell type and context dependent, Notch signaling can lead to the initiation of EMT by activating nuclear factor- $\mathrm{\kappa B}(\mathrm{NF}-\mathrm{\kappa} \mathrm{B})$ or altering TGF- $\beta$ signaling $[38,39]$. The evolutionarily conserved Numb acts to regulate Notch activity by interacting with NICD, leading to NICD polyubiquitination and degradation [40]. Numb-mediated Notch inhibition is disrupted in approximately $50 \%$ of breast carcinomas, due to degradation of Numb [41]. A relationship between overexpression of Notch signaling and poor overall survival in breast cancer patients has also been observed [42]. Most recently, Notch signaling was shown to have an important role in breast cancer bone metastasis pathophysiology. Notch signaling requires coordinated interaction with other pathways to induce EMT. During embryogenesis, Notch signaling coordinates Jagged 1, a Notch ligand, and $H E Y 1$, a Notch target gene, signaling in a Smad3dependent fashion [43].

\section{TGF- $\beta$ signaling}

TGF- $\beta$ signaling also plays a significant role in the process of EMT, embryogenesis, and cancer pathogenesis. Key are the TGF- $\beta$-induced transcription factors Snail (SNAI1 and SNAI2/Slug), Twist (basic helix-loop-helix), Six family 


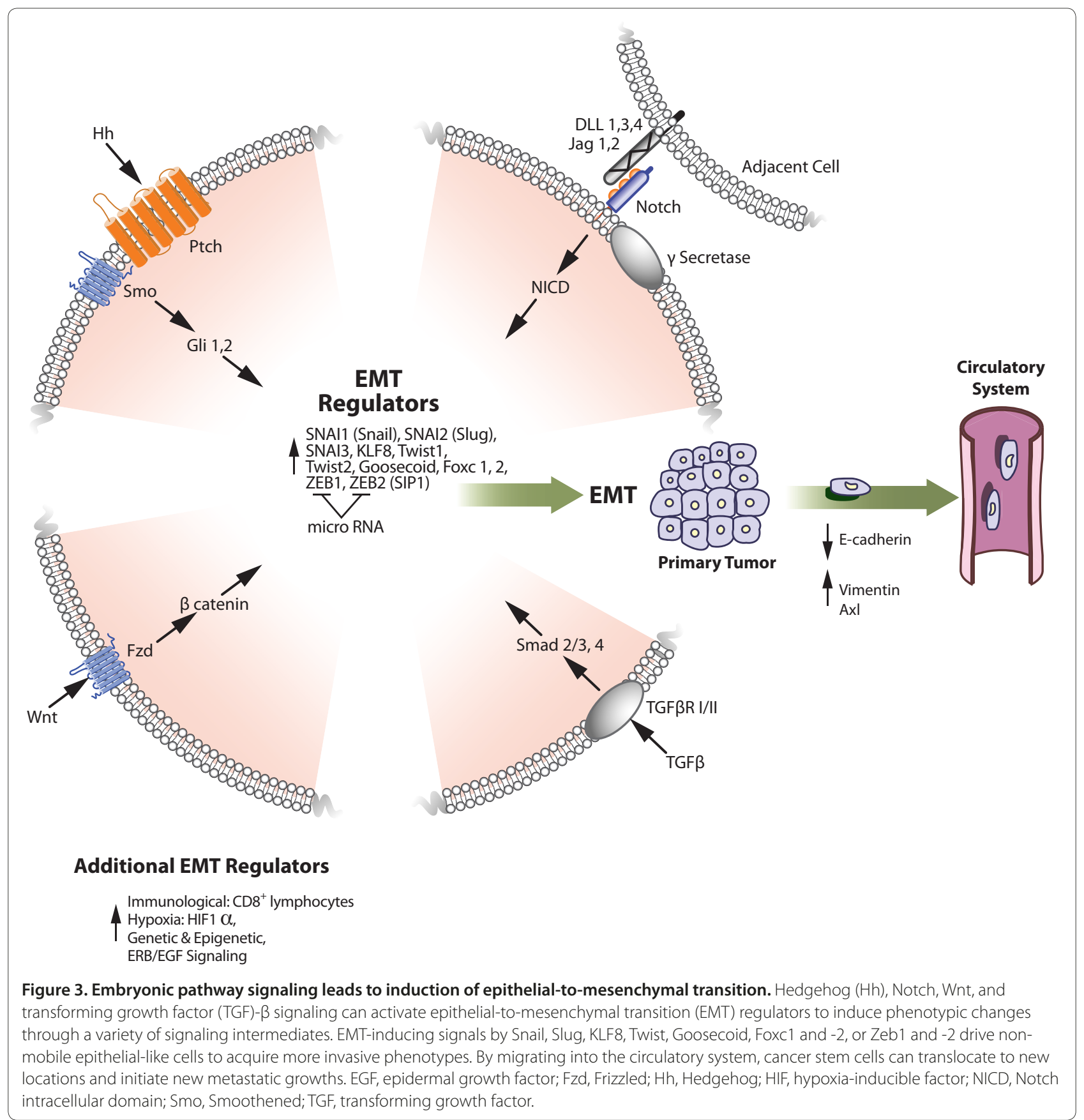

homeobox (Six1) and ZEB (ZEB1 and ZEB2/SIP1) (Figure 3). In breast CSCs, TGF- $\beta$ signaling appears to modulate stem cell phenotype and maintain pluripotency $[31,38,44,45]$. TGF- $\beta$ can alter tight junction formation in mammary epithelium and induce signaling in a number of embryonic signaling pathways, including Wnt, Notch, and Hh pathways. During EMT, SNAI1 and SNAI2/Slug (Snail) associate with SMAD3 and SMAD4 in the TGF- $\beta$ signaling pathway to initiate cancer growth and metastasis by inhibiting or suppressing transcription of E-cadherin, occludin and claudin $[46,47]$.

\section{Hedgehog signaling}

The Hh ligands Sonic (SHh), Desert (DHh) and Indian (IHh), mediate embryogenesis by defining polarity, morphogenesis, proliferation and differentiation [48]. Hh signaling modulates tissue polarity and is responsible for stem cell maintenance. The Hh ligands bind to a 12-pass transmembrane protein, Patched (PTCH) [49], and binding results in the de-repression of Smoothened (SMO) [50]. SMO then translocates to the primary cilium, which is then internalized and activated. Signaling then proceeds to activate the zinc-finger transcription factors GLI-1, -2 
and -3, leading to transcription of GLI target genes. The balance between the GLI- 1 and - 2 activators and the GLI-2 and -3 repressor forms moderates Hh signaling [51].

EMT and metastases are blocked by SMO antagonists/ inhibitors in cell lines from pancreatic cancer [52,53]. For example, cyclopamine, a SMO antagonist, diminished motility and growth of cells $[54,55]$. Hh signaling plays a pivotal role in EMT by inducing the expression of a repressor of E-cadherin, SNAIL1 [56,57]. High GLI1 is seen in colorectal xenografts with high metastatic potential, epithelial morphology and EMT-associated markers [58]. In this model E-CADHERIN was also suppressed. While evaluating CSCs in the immunocompromised SCID mouse model is useful, it presents limitations for evaluating the role of the immune system, and in particular cytokines, in tumorigenesis and the development of metastases.

\section{Wnt/ $\beta$-catenin signaling}

The Wnt signaling pathway controls development of the mammary gland during embryogenesis and growth and differentiation of the breast during pregnancy and lactation [59]. Currently there are 19 known Wnt genes, 10 Frizzled (Fzd) receptors, and 2 low density lipoprotein receptor-related protein (LRP) co-receptors [60].

In the inactive state, cytoplasmic $\beta$-catenin is depleted from the cell via the destruction complex consisting of adenomatous polyposis coli (APC), glycogen synthase kinase $3 \beta$ (GSK3 $\beta$ ), Axin, and casein kinase-1 $\alpha$ [61]. During Wnt signaling, activity of the destruction complex is inhibited, allowing accumulation and translocation of $\beta$-catenin to the nucleus, where it interacts with the lymphoid enhancer factor/T cell factor (Lef/Tcf) complex leading to targeted gene transcription.

Wnt signaling can be broadly grouped as either canonical/ $\beta$-catenin or non-canonical. Canonical signaling, the result of Wnt binding to Fzd, leads to $\beta$-catenin accumulation within the cell nucleus. $\beta$-catenin accumulation within the nucleus or cytoplasm has been reported in approximately $50 \%$ of breast carcinomas and has been correlated with poor prognosis [62]. Non-canonical Wnt signaling does not result in $\beta$-catenin accumulation in the nucleus.

\section{Tumor metastasis}

The dissemination of cancer cells may occur at an early stage of malignancy, but tumor cell dormancy, a time lag between tissue infiltration and tumor formation, may result in metastatic latency $[63,64]$. Understanding the sequential stepwise events during metastasis is essential for the development of novel therapeutic agents. However, considering the differences in target organs and rates of metastatic growth, optimizing therapeutic interventions remains challenging.
The relationship between the niche microenvironment and metastasis was first demonstrated by the characterization of bone marrow-derived cells that were directed to and colonized the pre-metastatic niche [65]. The recruitment of bone marrow-derived cells to the pre-metastatic niche may involve a variety of secreted factors, including osteopontin [66]. Weakly metastatic human breast cancer cells could be induced to form metastatic tumors in mice when mixed with bone marrow-derived mesenchymal stem cells [67]. Induction of tumor formation was reversible and dependent on chemokine CCL5 (RANTES) signaling through the CCR5 receptor. These studies suggest a link between cytokine concentrations in the stem cell microenvironment and induction of metastatic tumor growth.

Gene expression studies performed on human breast cancer specimens have identified a breast cancer molecular subtype 'claudin-low' population [68] that expresses an overlapping gene signature with that of CSC populations enriched with $\mathrm{CD} 44^{+} / \mathrm{CD} 24^{- \text {llow }}$ cells using fluorescence-activated cell sorting (FACS), and mammospheres [69]. Claudin-low breast tumors are typically 'triple negative' invasive, ductal carcinomas associated with a poor prognosis. Using genetically modified cell lines, the 'claudin-low' population expressed low levels of Claudin 3 and E-cadherin and also expressed EMT markers such as vimentin and Twist, suggesting that claudin-low cells may have derived from immature progenitor or stem cells [70]. An EMT gene expression signature in human mammary epithelial cells, produced by overexpressing either Goosecoid (Gsc), Snail, Twist, or TGF- $\beta 1$, or by knocking down expression of Ecadherin, was found to be most similar to the gene expression signature found in claudin-low and metaplastic breast cancers. The EMT signature most closely resembled the gene signature of basal B cell lines, characterized by high vimentin expression and a cancer stem cell-like profile.

\section{Epithelial-to-mesenchymal transition}

Deregulation of EMT, an essential process during embryogenesis and adult tissue repair and maintenance, may result in the mobilization and spread of primary tumor cells to distant locations. When adherent epithelial cells acquire mesenchymal properties, gene-expression patterns change and the cells acquire an increased motility potential. In the case of cancer, EMT and MET may serve to regulate cellular plasticity and play important roles during tumor invasion, metastasis, and therapeutic resistance [71].

EMT is also linked with the acquisition of stem cell characteristics [44]. The concept of CSCs conferring both EMT and self-renewal properties provides the rationale for cancer cells to migrate and populate metastatic sites. 
It also provides the rationale for targeting the CSC population with anti-tumor therapies to inhibit metastasis.

\section{Regulators of epithelial-to-mesenchymal transition} The functional loss of E-cadherin is the most critical event linked with EMT. The loss of these membrane adhesive proteins allows previously stationary tumor cells to dislodge from their original location and become more mobile. E-cadherin expression is controlled by various mechanisms, including inactivating mutations [72], epigenetic modulation through promoter hypermethylation [73], and transcriptional repression by zinc-finger transcription factors with high affinity for the E-box elements of E-cadherin promoter [74,75]. At the metastatic site, in the absence of additional EMT modulators in the stromal microenvironment, the cell transforms back to the original epithelial phenotype (via MET) [76]. This important concept suggests that transcription of the E-cadherin gene, or post-translational modification, may be partly controlled by epigenetic mechanisms.

\section{Epigenetic and DNA mutations}

Hypermethylation and silencing of the E-cadherin promoter is known to cause transcriptional down-regulation of the E-cadherin gene and is linked to the initiation of EMT, migration and invasion in breast cancer [73,77]. Reversibility of E-cadherin expression seems to be associated with the tumor progression and metastasis caused by EMT and MET [78]. These findings demonstrate that reduced E-cadherin expression may be linked with epigenetic modulation, due to partial methylation of the E-cadherin promoter region. More recently, a role of TGF- $\beta$ has been identified to maintain DNA methylation patterns during EMT and sustain the silencing of E-cadherin and other tight junction genes [79].

\section{microRNAs}

microRNAs (miRNAs) are a new class of EMT regulators, functioning to modify EMT-inducing transcription factors [80]. miRNAs act by inhibiting gene expression at the post-transcriptional level by suppression of sequence complementary mRNA targets [81]. Since each small interfering RNA can interact with dozens of target mRNAs, their impact on gene expression can be significant. Members of the miR-200 family suppress tumor cell motility and invasiveness in vitro and inhibit induction of EMT through downregulation of ZEB1 and ZEB2 and the subsequent increase in E-cadherin expression [82]. Down-regulation of miR-200 was sufficient to reduce E-cadherin expression and induce EMT. Thus, modulating the expression of particular miRNAs is likely to effect tumorigenesis and may play a role in tumor metastasis as well [83].
The presence of miR-335 has been linked with suppression of metastasis in human breast cancer [84]. In a study of 20 primary human breast tumors, the expression of miR-335 was inversely associated with the formation of metastatic lesions. Results suggested that miR-335 helped down-regulate metastatic genes in breast cancer, and the loss of miR-335 may serve as a negative prognostic indicator. The important role that miRNAs play in the regulation of EMT suggests they may also serve as potential therapeutic targets.

\section{Transcription factors}

At least ten transcription factors have been identified as EMT regulators during embryogenesis and/or carcinogenesis (Figure 3) $[56,85]$. Besides ZEB1 and ZEB2, the following transcription factors directly repress the $C D H 1$ gene encoding E-cadherin: SNAI1, SNAI2 (SLUG), SNAI3, TWIST1, FOXC1, FOXC2, GSC (goosecoid), and KLF8. Extensive cross-talk among these transcription factors is necessary to maintain mesenchymal cell phenotypes [85]. Furthermore, these EMT-inducing transcription factors play a role in acquisition of stem cell characteristics as these factors are expressed at much higher levels in CD44+/CD24- breast CSC-like cells than in more differentiated epithelial cells $[44,86]$.

\section{Bmi1}

The polycomb group protein Bmi-1 (B lymphoma MoMLV insertion region 1 homologue) also plays a role in epigenetic gene-silencing and affects embryonic development and oncogenesis [87]. Bmi-1's role in breast cancer invasion and metastasis has been speculated, but details remain elusive. Recently, Song and colleagues [88] studied the Bmi-1 role in human nasopharyngeal epithelial cells and showed a direct association between Bmi1-1 and EMT. This report also revealed that EMT induction was due to the direct binding of Bmi-1 to the phosphatase and tensin homologue (PTEN) locus causing down-regulated expression of PTEN. Subsequent activation of the PI3K/Akt pathway stabilized Snail and down-regulated E-cadherin. Bmi-1 may become a therapeutic target in CSCs, not only modulating the self-renewal potential of these cells, but also inhibiting EMT and preventing stem cells from acquiring invasive properties.

\section{Immune regulation}

In addition to its well known function for accelerating cell invasion, SNAI1 has been demonstrated to contribute to enhancing metastasis by inducing immunosuppression through multiple mechanisms [89]. SNAI1 ${ }^{+}$melanoma was observed to induce severe immunosuppression both in vitro and in vivo. In mice, enhanced tumor metastasis was achieved through suppression of nearly all antitumor effector cells at the local tumor site in vivo. Almost no 
infiltration of effector cells was observed. Thus, expression of SNAI1-induced EMT and immunosuppression of the tumor-bearing host accelerate tumor metastasis simultaneously. Even tumors expressing low levels of SNAI1 might cause immunosuppression, suggesting that targeting SNAI1 may help prevent metastasis.

\section{Epidermal growth factor receptor regulation}

Expression of the ErbB receptor tyrosine kinase family and their ligands has been detected in various cancers and is particularly important in breast cancer, where it is associated with poor prognosis. Epidermal growth factor receptor (EGFR) signaling can induce EMT, invasion and metastasis via induction of Snail and ZEB [90]. EGFR/ ErbB2 heterodimers could induce mammary epithelial cells to acquire invasive properties [91]. Inhibition of ErbB receptor signaling reversed an aggressive inflammatory breast cancer phenotype into an epithelial-like phenotype in vitro [92]. Korkaya and colleagues [32] demonstrated that HER2 (ErbB2) stimulated the selfrenewal of breast cancer stem cells through the PI3K/Akt pathway. Their study provided the therapeutic rationale to treat chemotherapy-resistant breast CSCs with the EGFR/HER2 inhibitor lapatinib [18]. Due to limited clinical efficacy with ErbB inhibitors alone, a combination approach may provide improved clinical outcome.

\section{Microenvironment and cytokines}

Extracellular factors related to tumor microenvironment are known to induce EMT. For example, matrix metalloproteinase (MMP) family proteins were found to cause mammary epithelial cell invasion by inducing EMT $[93,94]$. It is likely that EMT-inducing signals are released by mesenchymal cells into the tumor microenvironment and confer on tumor cells invasive and metastatic characteristics [67]. Moreover, these signals are released by more activated and inflamed stroma surrounded by progressive tumors [76]. The concept of activated stroma releasing EMT-inducing transcription factors into the microenvironment suggests that when tumor cells metastasize to distant sites, these stromal cells may not be activated. In the absence of EMT-inducing signals, the metastasized tumor cells may revert to their epithelial phenotype (MET). For example, Mori and colleagues [95] reported that mouse mammary epithelial cells underwent malignant transformation, including loss of cell-to-cell contact, when exposed to long-term oxidative stress.

\section{Conclusion}

Preventing the induction of EMT in primary breast cancer may serve as a novel mechanism to potentially inhibit the spread of metastatic disease. Activation of embryonic signaling pathways (that is, Notch, Wnt, Hh, and TGF- $\beta$ ) and their downstream transcription factors are responsible for driving EMT, resulting in the transformation of epithelial-like CSCs into cells with aggressive mesenchymal-like phenotypes. These invasive CSCs have the potential to travel to distant sites and initiate metastatic tumors. Therapies directed towards inhibiting the induction of EMT may therefore reduce the formation of mesenchymal-like CSCs and improve clinical outcome.

In parallel with the development of this therapeutic approach, it is crucial to identify a more detailed molecular signature of the primary tumor in order to more accurately predict which patient population would benefit from this type of long-term therapy. By examining embryonic pathway signaling at the tumor microenvironmental level, one may better predict future metastatic potential. In high risk patients, therapeutic approaches directed at modulation of embryonic signaling pathways may be beneficial.

Another promising approach to inhibit metastasis centers on developing molecular assays to identify which dormant tumor cells will acquire metastatic potential. Tumor dormancy is relatively unique to breast cancer as some disseminated tumor cells remain quiescent, while others metastasize to distant organs. For example, bone marrow micrometastases are commonly seen in early stage breast cancer. Targeting bone marrow disseminated tumors at an early stage with adjuvant therapy may be beneficial to those with high risk for future distant metastasis. Alternatively, therapies designed to mobilize or stimulate dormant CSCs to undergo cell division may subsequently increase their sensitivity to currently available cytotoxic therapeutics.

Finally, the interrelationship between CSCs, embryonic signaling pathways, and EMT/MET offers a continuum of potential therapeutic targets. Knowledge of this relationship is important for both the researcher and clinician in developing and administering optimal therapies for breast cancer patients.

\section{Abbreviations}

ABC, ATP-binding cassette; ALDH, aldehyde dehydrogenase; CSC, cancer stem cell; EGFR, epidermal growth factor receptor; EMT, epithelial-tomesenchymal transition; ER, estrogen receptor; Fzd, Frizzled; Hh, Hedgehog; MET, mesenchymal-to-epithelial transition; miRNA, microRNA; NICD, Notch intracellular domain; PI3K, phosphoinositide 3-kinase; SMO, Smoothened; TGF, transforming growth factor.

\section{Competing interests}

The authors declare that they have no competing interests.

\section{Author details}

'National Cancer Institute, Division of Cancer Treatment and Diagnosis, Cancer Therapy Evaluation Program, Investigational Drug Branch, EPN 7131, 6130 Executive Boulevard, Rockville, Maryland 20852, USA . 3PSI International, Inc., 6500 Rock Spring Dr., Suite 650, Bethesda, Maryland 20817, USA.

Published: 10 June 2011

References

1. O'Brien CA, Kreso A, Jamieson CH: Cancer stem cells and self-renewal. Clin Cancer Res 2010, 16:3113-3120. 
2. Shackleton M, Quintana E, Fearon ER, Morrison SJ: Heterogeneity in cancer: cancer stem cells versus clonal evolution. Cell 2009, 138:822-829.

3. Kelleher FC, Fennelly D, Rafferty M: Common critical pathways in embryogenesis and cancer. Acta Oncol 2006, 45:375-388.

4. Huang CL, Liu D, Ishikawa S, Nakashima T, Nakashima N, Yokomise H, Kadota K, Ueno M: Wnt1 overexpression promotes tumour progression in nonsmall cell lung cancer. Eur J Cancer 2008, 44:2680-2688.

5. Liu CC, Prior J, Piwnica-Worms D, Bu G: LRP6 overexpression defines a class of breast cancer subtype and is a target for therapy. Proc Natl Acad Sci U S A 2010, 107:5136-5141.

6. Mullendore ME, Koorstra JB, Li YM, Offerhaus GJ, Fan X, Henderson CM, Matsui W, Eberhart CG, Maitra A, Feldmann G: Ligand-dependent Notch signaling is involved in tumor initiation and tumor maintenance in pancreatic cancer. Clin Cancer Res 2009, 15:2291-2301.

7. Petersen OW, Polyak K: Stem cells in the human breast. Cold Spring Harb Perspect Biol 2011, 2:a003160.

8. Takebe N, Ivy SP: Controversies in cancer stem cells: targeting embryonic signaling pathways. Clin Cancer Res 2010, 16:3106-3112.

9. Venkitaraman AR: Cancer susceptibility and the functions of BRCA1 and BRCA2. Cell 2002, 108:171-182.

10. Liu S, Ginestier C, Charafe-Jauffret E, Foco H, Kleer CG, Merajver SD, Dontu G, Wicha MS: BRCA1 regulates human mammary stem/progenitor cell fate. Proc Natl Acad Sci U SA 2008, 105:1680-1685.

11. Grimshaw MJ, Cooper L, Papazisis K, Coleman JA, Bohnenkamp HR, ChiaperoStanke L, Taylor-Papadimitriou J, Burchell JM: Mammosphere culture of metastatic breast cancer cells enriches for tumorigenic breast cancer cells. Breast Cancer Res 2008, 10:R52.

12. Al-Hajj M, Wicha MS, Benito-Hernandez A, Morrison SJ, Clarke MF: Prospective identification of tumorigenic breast cancer cells. Proc Natl Acad Sci U S A 2003, 100:3983-3988.

13. Wright MH, Calcagno AM, Salcido CD, Carlson MD, Ambudkar SV, Varticovski $L:$ Brca1 breast tumors contain distinct CD44+/CD24- and CD133+ cells with cancer stem cell characteristics. Breast Cancer Res 2008, 10:R10.

14. Lim E, Vaillant F, Wu D, Forrest NC, Pal B, Hart AH, Asselin-Labat ML, Gyorki DE, Ward T, Partanen A, Feleppa F, Huschtscha LI, Thorne HJ; KConFab, Fox SB, Yan M, French JD, Brown MA, Smyth GK, Visvader JE, Lindeman GJ: Aberrant luminal progenitors as the candidate target population for basal tumor development in BRCA1 mutation carriers. Nat Med 2009, 15:907-913.

15. Ginestier C, Hur MH, Charafe-Jauffret E, Monville F, Dutcher J, Brown M, Jacquemier J, Viens P, Kleer CG, Liu S, Schott A, Hayes D, Birnbaum D, Wicha MS, Dontu G: ALDH1 is a marker of normal and malignant human mammary stem cells and a predictor of poor clinical outcome. Cell Stem Cell 2007, 1:555-567.

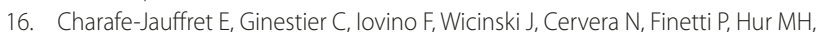
Diebel ME, Monville F, Dutcher J, Brown M, Viens P, Xerri L, Bertucci F, Stassi G, Dontu G, Birnbaum D, Wicha MS: Breast cancer cell lines contain functional cancer stem cells with metastatic capacity and a distinct molecular signature. Cancer Res 2009, 69:1302-1313.

17. Mbeunkui F, Johann DJ Jr: Cancer and the tumor microenvironment: a review of an essential relationship. Cancer Chemother Pharmacol 2009, 63:571-582.

18. Li X, Lewis MT, Huang J, Gutierrez C, Osborne CK, Wu MF, Hilsenbeck SG, Pavlick A, Zhang X, Chamness GC, Wong H, Rosen J, Chang JC: Intrinsic resistance of tumorigenic breast cancer cells to chemotherapy. J Nat/ Cancer Inst 2008, 100:672-679.

19. Ding XW, Wu JH, Jiang CP: ABCG2: a potential marker of stem cells and novel target in stem cell and cancer therapy. Life Sci 2010, 86:631-637.

20. Doyle LA, Yang W, Abruzzo LV, Krogmann T, Gao Y, Rishi AK, Ross DD: A multidrug resistance transporter from human MCF-7 breast cancer cells. Proc Natl Acad Sci U S A 1998, 95:15665-15670.

21. Ni Z, Bikadi Z, Rosenberg MF, Mao Q: Structure and function of the human breast cancer resistance protein (BCRP/ABCG2). Curr Drug Metab 2010, 11:603-617.

22. Phillips TM, MCBride WH, Pajonk F: The response of CD24(-/low)/CD44+ breast cancer-initiating cells to radiation. J Natl Cancer Inst 2006, 98:1777-1785.

23. Lagadec C, Vlashi E, Della Donna L, Meng Y, Dekmezian C, Kim K, Pajonk F: Survival and self-renewing capacity of breast cancer initiating cells during fractionated radiation treatment. Breast Cancer Res 2010, 12:R13.

24. Diehn M, Cho RW, Lobo NA, Kalisky T, Dorie MJ, Kulp AN, Qian D, Lam JS, Ailles LE, Wong M, Joshua B, Kaplan MJ, Wapnir I, Dirbas FM, Somlo G, Garberoglio
C, Paz B, Shen J, Lau SK, Quake SR, Brown JM, Weissman IL, Clarke MF: Association of reactive oxygen species levels and radioresistance in cancer stem cells. Nature 2009, 458:780-783.

25. Trumpp A, Wiestler OD: Mechanisms of disease: cancer stem cells targeting the evil twin. Nat Clin Pract Oncol 2008, 5:337-347.

26. Woodward WA, Chen MS, Behbod F, Alfaro MP, BuchholzTA, Rosen JM: WNT/ beta-catenin mediates radiation resistance of mouse mammary progenitor cells. Proc Natl Acad Sci U S A 2007, 104:618-623.

27. LaBarge MA: The difficulty of targeting cancer stem cell niches. Clin Cancer Res 2010, 16:3121-3129.

28. Moore KA, Lemischka IR: Stem cells and their niches. Science 2006, 311:1880-1885.

29. Takebe N, Harris PJ, Warren RQ, IVy SP: Targeting cancer stem cells by inhibiting Wnt, Notch, and Hedgehog pathways. Nat Rev Clin Oncol, 8:97-106.

30. Guo X, Wang XF: Signaling cross-talk between TGF-beta/BMP and other pathways. Cell Res 2009, 19:71-88.

31. Massaque J: TGFbeta in Cancer. Cell 2008, 134:215-230.

32. Korkaya H, Paulson A, lovino F, Wicha MS: HER2 regulates the mammary stem/progenitor cell population driving tumorigenesis and invasion. Oncogene 2008, 27:6120-6130.

33. Chen Y, Fischer WH, Gill GN: Regulation of the ERBB-2 promoter by RBPJkappa and NOTCH. J Biol Chem 1997, 272:141 10-14114.

34. Magnifico A, Albano L, Campaner S, Delia D, Castiglioni F, Gasparini P, Sozzi G, Fontanella E, Menard S, Tagliabue E: Tumor-initiating cells of HER2-positive carcinoma cell lines express the highest oncoprotein levels and are sensitive to trastuzumab. Clin Cancer Res 2009, 15:2010-2021.

35. Rizzo P, Miao H, D'Souza G, Osipo C, Song LL, Yun J, Zhao H, Mascarenhas J, Wyatt D, Antico G, Hao L, Yao K, Rajan P, Hicks C, Siziopikou K, Selvaggi S, Bashir A, Bhandari D, Marchese A, Lendahl U, Qin JZ, Tonetti DA, Albain K, Nickoloff BJ, Miele L: Cross-talk between notch and the estrogen receptor in breast cancer suggests novel therapeutic approaches. Cancer Res 2008, 68:5226-5235.

36. Artavanis-Tsakonas S, Rand MD, Lake RJ: Notch signaling: cell fate control and signal integration in development. Science 1999, 284:770-776.

37. Pannuti A, Foreman K, Rizzo P, Osipo C, Golde T, Osborne B, Miele L: Targeting Notch to target cancer stem cells. Clin Cancer Res 2010, 16:3141-3152.

38. Polyak K, Weinberg RA: Transitions between epithelial and mesenchymal states: acquisition of malignant and stem cell traits. Nat Rev Cancer 2009, 9:265-273.

39. Wang Z, Banerjee S, Li Y, Rahman KM, Zhang Y, Sarkar FH: Down-regulation of notch-1 inhibits invasion by inactivation of nuclear factor-kappaB, vascular endothelial growth factor, and matrix metalloproteinase-9 in pancreatic cancer cells. Cancer Res 2006, 66:2778-2784.

40. McGill MA, McGlade CJ: Mammalian numb proteins promote Notch1 receptor ubiquitination and degradation of the Notch1 intracellular domain. J Biol Chem 2003, 278:23196-23203.

41. Pece S, Serresi M, Santolini E, Capra M, Hulleman E, Galimberti V, Zurrida S, Maisonneuve P, Viale G, Di Fiore PP: Loss of negative regulation by Numb over Notch is relevant to human breast carcinogenesis. J Cell Biol 2004, 167:215-221

42. Reedijk M, Odorcic S, Chang L, Zhang H, Miller N, McCready DR, Lockwood G, Egan SE: High-level coexpression of JAG1 and NOTCH1 is observed in human breast cancer and is associated with poor overall survival. Cancer Res 2005, 65:8530-8537.

43. Zavadil J, Cermak L, Soto-Nieves N, Bottinger EP: Integration of TGF-beta/ Smad and Jagged $1 /$ Notch signalling in epithelial-to-mesenchymal transition. EMBO J 2004, 23:1155-1165.

44. Mani SA, Guo W, Liao MJ, Eaton EN, Ayyanan A, Zhou AY, Brooks M, Reinhard F, Zhang CC, Shipitsin M, Campbell LL, Polyak K, Brisken C, Yang J, Weinberg RA: The epithelial-mesenchymal transition generates cells with properties of stem cells. Cell 2008, 133:704-715.

45. Yang J, Weinberg RA: Epithelial-mesenchymal transition: at the crossroads of development and tumor metastasis. Dev Cell 2008, 14:818-829.

46. Ikenouchi J, Matsuda M, Furuse M, Tsukita S: Regulation of tight junctions during the epithelium-mesenchyme transition: direct repression of the gene expression of claudins/occludin by Snail. J Cell Sci 2003, 116:1959-1967.

47. Vincent T, Neve EP, Johnson JR, Kukalev A, Rojo F, Albanell J, Pietras K, Virtanen I, Philipson L, Leopold PL, Crystal RG, de Herreros AG, Moustakas A, Pettersson RF, Fuxe J: A SNAIL1-SMAD3/4 transcriptional repressor complex promotes 
TGF-beta mediated epithelial-mesenchymal transition. Nat Cell Biol 2009, 11:943-950.

48. Ingham PW, McMahon AP: Hedgehog signaling in animal development: paradigms and principles. Genes Dev 2001, 15:3059-3087.

49. Pepinsky RB, Rayhorn P, Day ES, Dergay A, Williams KP, Galdes A, Taylor FR, Boriack-Sjodin PA, Garber EA: Mapping sonic hedgehog-receptor interactions by steric interference. J Biol Chem 2000, 275:10995-1 1001.

50. Murone M, Rosenthal A, de Sauvage FJ: Sonic hedgehog signaling by the patched-smoothened receptor complex. Curr Bio/ 1999, 9:76-84.

51. Cayuso J, Ulloa F, Cox B, Briscoe J, Marti E: The Sonic hedgehog pathway independently controls the patterning, proliferation and survival of neuroepithelial cells by regulating Gli activity. Development 2006, 133:517-528.

52. Feldmann G, Dhara S, Fendrich V, Bedja D, Beaty R, Mullendore M, Karikari C, Alvarez H, lacobuzio-Donahue C, Jimeno A, Gabrielson KL, Matsui W, Maitra A: Blockade of hedgehog signaling inhibits pancreatic cancer invasion and metastases: a new paradigm for combination therapy in solid cancers. Cancer Res 2007, 67:2187-2196.

53. Hay ED: An overview of epithelio-mesenchymal transformation. Acta Anat (Basel) 1995, 154:8-20.

54. Karhadkar SS, Bova GS, Abdallah N, Dhara S, Gardner D, Maitra A, Isaacs JT, Berman DM, Beachy PA: Hedgehog signalling in prostate regeneration, neoplasia and metastasis. Nature 2004, 431:707-712.

55. Louro ID, Bailey EC, Li X, South LS, McKie-Bell PR, Yoder BK, Huang CC, Johnson MR, Hill AE, Johnson RL, Ruppert JM: Comparative gene expression profile analysis of GLI and c-MYC in an epithelial model of malignant transformation. Cancer Res 2002, 62:5867-5873.

56. Katoh $Y$, Katoh M: Hedgehog signaling, epithelial-to-mesenchymal transition and miRNA (review). Int J Mol Med 2008, 22:271-275.

57. Merchant AA, Matsui W: Targeting Hedgehog - a cancer stem cell pathway. Clin Cancer Res 2010, 16:3130-3140.

58. Varnat F, Duquet A, Malerba M, Zbinden M, Mas C, Gervaz P, Ruiz i Altaba A: Human colon cancer epithelial cells harbour active HEDGEHOG-GLI signalling that is essential for tumour growth, recurrence, metastasis and stem cell survival and expansion. EMBO Mol Med 2009, 1:338-351.

59. Prosperi JR, Goss KH: A Wnt-ow of opportunity: targeting the Wnt/betacatenin pathway in breast cancer. Curr Drug Targets 2010, 11:1074-1088.

60. Nusse R: Wnt signaling in disease and in development. Cell Res 2005, 15:28-32.

61. Gordon MD, Nusse R: Wnt signaling: multiple pathways, multiple receptors, and multiple transcription factors. J Biol Chem 2006, 281:22429-22433.

62. Lin SY, Xia W, Wang JC, Kwong KY, Spohn B, Wen Y, Pestell RG, Hung MC Beta-catenin, a novel prognostic marker for breast cancer: its roles in cyclin D1 expression and cancer progression. Proc Natl Acad Sci U S A 2000, 97:4262-4266

63. Karrison TG, Ferguson DJ, Meier P: Dormancy of mammary carcinoma after mastectomy. J Natl Cancer Inst 1999, 91:80-85.

64. Schmidt-Kittler O, Ragg T, Daskalakis A, Granzow M, Ahr A, Blankenstein TJ, Kaufmann M, Diebold J, Arnholdt H, Muller P, Bischoff J, Harich D, Schlimok G, Riethmuller G, Eils R, Klein CA: From latent disseminated cells to overt metastasis: genetic analysis of systemic breast cancer progression. Proc Natl Acad SciU S A 2003, 100:7737-7742.

65. Kaplan RN, Riba RD, Zacharoulis S, Bramley AH, Vincent L, Costa C, MacDonald DD, Jin DK, Shido K, Kerns SA, Zhu Z, Hicklin D, Wu Y, Port JL, Altorki N, Port ER, Ruggero D, Shmelkov SV, Jensen KK, Rafii S, Lyden D: VEGFR1-positive haematopoietic bone marrow progenitors initiate the pre-metastatic niche. Nature 2005, 438:820-827.

66. Furger KA, Menon RK, Tuck AB, Bramwell VH, Chambers AF: The functional and clinical roles of osteopontin in cancer and metastasis. Curr Mol Med 2001, 1:621-632

67. Karnoub AE, Dash AB, Vo AP, Sullivan A, Brooks MW, Bell GW, Richardson AL, Polyak K, Tubo R, Weinberg RA: Mesenchymal stem cells within tumour stroma promote breast cancer metastasis. Nature 2007, 449:557-563.

68. Herschkowitz II, Simin K, Weigman VJ, Mikaelian I, Usary J, Hu Z, Rasmussen KE, Jones LP, Assefnia S, Chandrasekharan S, Backlund MG, Yin Y, Khramtsov Al, Bastein R, Quackenbush J, Glazer Rl, Brown PH, Green JE, Kopelovich L, Furth PA, Palazzo JP, Olopade OI, Bernard PS, Churchill GA, Van Dyke T, Perou $\mathrm{CM}$ : Identification of conserved gene expression features between murine mammary carcinoma models and human breast tumors. Genome Biol 2007 8:R76.

69. Creighton CJ, Li X, Landis M, Dixon JM, Neumeister VM, Sjolund A, Rimm DL,
Wong H, Rodriguez A, Herschkowitz Jl, Fan C, Zhang X, He X, Pavlick A, Gutierrez MC, Renshaw L, Larionov AA, Faratian D, Hilsenbeck SG, Perou CM, Lewis MT, Rosen JM, Chang JC: Residual breast cancers after conventional therapy display mesenchymal as well as tumor-initiating features. Proc Natl Acad SciU S A 2009, 106:13820-13825.

70. Taube JH, Herschkowitz Jl, Komurov K, Zhou AY, Gupta S, Yang J, Hartwell K, Onder TT, Gupta PB, Evans KW, Hollier BG, Ram PT, Lander ES, Rosen JM, Weinberg RA, Mani SA: Core epithelial-to-mesenchymal transition interactome gene-expression signature is associated with claudin-low and metaplastic breast cancer subtypes. Proc Natl Acad Sci U S A 2010, 107:15449-15454.

71. Thiery JP: Epithelial-mesenchymal transitions in tumour progression. Nat Rev Cancer 2002, 2:442-454

72. Berx G, Becker KF, Hofler H, van Roy F: Mutations of the human E-cadherin (CDH1) gene. Hum Mutat 1998, 12:226-237.

73. Lombaerts M, van Wezel T, Philippo K, Dierssen JW, Zimmerman RM, Oosting J, van Eijk R, Eilers PH, van de Water B, Cornelisse CJ, Cleton-Jansen AM: E-cadherin transcriptional downregulation by promoter methylation but not mutation is related to epithelial-to-mesenchymal transition in breast cancer cell lines. Br J Cancer 2006, 94:661-671.

74. Batlle E, Sancho E, Franci C, Dominguez D, Monfar M, Baulida J, Garcia De Herreros A: The transcription factor snail is a repressor of $\mathrm{E}$-cadherin gene expression in epithelial tumour cells. Nat Cell Biol 2000, 2:84-89.

75. Cano A, Perez-Moreno MA, Rodrigo I, Locascio A, Blanco MJ, del Barrio MG, Portillo F, Nieto MA: The transcription factor snail controls epithelialmesenchymal transitions by repressing E-cadherin expression. Nat Cell Biol 2000, 2:76-83.

76. Weinberg RA: Mechanisms of malignant progression. Carcinogenesis 2008, 29:1092-1095.

77. Graff JR, Herman JG, Lapidus RG, Chopra H, Xu R, Jarrard DF, Isaacs WB, Pitha PM, Davidson NE, Baylin SB: E-cadherin expression is silenced by DNA hypermethylation in human breast and prostate carcinomas. Cancer Res 1995, 55:5195-5199.

78. Kowalski PJ, Rubin MA, Kleer CG: E-cadherin expression in primary carcinomas of the breast and its distant metastases. Breast Cancer Res 2003, 5:R217-222.

79. Taylor MA, Parvani JG, Schiemann WP: The pathophysiology of epithelialmesenchymal transition induced by transforming growth factor-beta in normal and malignant mammary epithelial cells. J Mammary Gland Biol Neoplasia 2010, 15:169-190.

80. Nicoloso MS, Spizzo R, Shimizu M, Rossi S, Calin GA: MicroRNAs - the micro steering wheel of tumour metastases. Nat Rev Cancer 2009, 9:293-302.

81. Bartel DP: MicroRNAs: target recognition and regulatory functions. Cell 2009, 136:215-233

82. Korpal M, Lee ES, Hu G, Kang Y: The miR-200 family inhibits epithelialmesenchymal transition and cancer cell migration by direct targeting of E-cadherin transcriptional repressors ZEB1 and ZEB2.J Biol Chem 2008, 283:14910-14914.

83. Valastyan S, Weinberg RA: MicroRNAs: crucial multi-tasking components in the complex circuitry of tumor metastasis. Cell Cycle 2009, 8:3506-3512

84. Tavazoie SF, Alarcon C, Oskarsson T, Padua D, Wang Q, Bos PD, Gerald WL, Massague J: Endogenous human microRNAs that suppress breast cancer metastasis. Nature 2008, 451:147-152.

85. Moreno-Bueno G, Portillo F, Cano A: Transcriptional regulation of cell polarity in EMT and cancer. Oncogene 2008, 27:6958-6969.

86. Morel AP, Lievre M, Thomas C, Hinkal G, Ansieau S, Puisieux A: Generation of breast cancer stem cells through epithelial-mesenchymal transition. PLoS One $2008,3: e 2888$

87. Pirrotta V: Polycombing the genome: PcG, trxG, and chromatin silencing Cell 1998, 93:333-336.

88. Song LB, Li J, Liao WT, Feng Y, Yu CP, Hu LJ, Kong QL, Xu LH, Zhang X, Liu WL, Li MZ, Zhang L, Kang TB, Fu LW, Huang WL, Xia YF, Tsao SW, Li M, Band V, Band $H$, Shi QH, Zeng YX, Zeng MS: The polycomb group protein Bmi-1 represses the tumor suppressor PTEN and induces epithelial-mesenchymal transition in human nasopharyngeal epithelial cells. J Clin Invest 2009, 119:3626-3636.

89. Kudo-Saito C, Shirako H, Takeuchi T, Kawakami Y: Cancer metastasis is accelerated through immunosuppression during Snail-induced EMT of cancer cells. Cancer Cell 2009, 15:195-206.

90. Hugo HJ, Wafai R, BlickT, Thompson EW, Newgreen DF: Staurosporine augments EGF-mediated EMT in PMC42-LA cells through actin 
depolymerisation, focal contact size reduction and Snail1 induction a model for cross-modulation. BMC Cancer 2009, 9:235.

91. Zhan L, Xiang B, Muthuswamy SK: Controlled activation of ErbB1/ErbB2 heterodimers promote invasion of three-dimensional organized epithelia in an ErbB1-dependent manner: implications for progression of ErbB2overexpressing tumors. Cancer Res 2006, 66:5201-5208.

92. Zhang D, LaFortune TA, Krishnamurthy S, Esteva FJ, Cristofanilli M, Liu P, Lucci A, Singh B, Hung MC, Hortobagyi GN, Ueno NT: Epidermal growth factor receptor tyrosine kinase inhibitor reverses mesenchymal to epithelial phenotype and inhibits metastasis in inflammatory breast cancer. Clin Cancer Res 2009, 15:6639-6648.

93. Nelson CM, Khauv D, Bissell MJ, Radisky DC: Change in cell shape is required for matrix metalloproteinase-induced epithelial-mesenchymal transition of mammary epithelial cells. J Cell Biochem 2008, 105:25-33.
94. Orlichenko LS, Radisky DC: Matrix metalloproteinases stimulate epithelialmesenchymal transition during tumor development. Clin Exp Metastasis 2008, 25:593-600.

95. Mori K, Shibanuma M, Nose K: Invasive potential induced under long-term oxidative stress in mammary epithelial cells. Cancer Res 2004, 64:7464-7472.

doi:10.1186/bcr2876

Cite this article as: Takebe $\mathrm{N}$, et al.: Breast cancer growth and metastasis: interplay between cancer stem cells, embryonic signaling pathways and epithelial-to-mesenchymal transition. Breast Cancer Research 2011, 13:211. 